\title{
ANAEROBIC TREATMENT OF SLAUGHTERHOUSE WASTEWATER: EVALUATING OPERATING CONDITIONS
}

\author{
MARTHA NORO CHOLLOM,${ }^{1}$ SUDESH RATHILAL ${ }^{1}$, FEROZ M. SWALAHA ${ }^{1}$, \\ BABATUNDE F. BAKARE ${ }^{2} \&$ EMMANUEL K. TETTEH ${ }^{1}$ \\ ${ }^{1}$ Durban University of Technology, South Africa \\ ${ }^{2}$ Mangosuthu University of Technology, South Africa
}

\begin{abstract}
The aim of the study was to elucidate the effect of process parameters on the performance of an upflow anaerobic sludge blanket reactor (UASB) that was treating slaughterhouse wastewater. The UASB reactor was operated continuously under mesophilic conditions to evaluate its performance with respect to the removal of organics and, at the same time, monitor biogas production. Organic loading rate (OLR) was varied while keeping the hydraulic retention time (HRT) constant. Chemical oxygen demand (COD) removal efficiency higher than $75 \%$ was achieved at an OLR of 9 kg.COD.m-3.d-1, with a HRT of $12 \mathrm{~h}$. Bulking sludge problems were not observed during the reactor operation period. Stability of the treatment process was achieved by the natural buffering of the system due to the produced alkalinity and also due to the characteristics of the wastewaters which was found to be rich in proteins and fatty acids.

Keywords: anaerobic digestion, hydraulic retention time, organic loading rate, chemical oxygen demand, slaughterhouse wastewaters, biogas.
\end{abstract}

\section{INTRODUCTION}

The slaughterhouses are important sources of waste generation, especially wastewater [1][3]. Various stages are involved during the slaughtering of animals, viz. receiving of the livestock, slaughtering operations, and separation of the carcass from the offal products, cleaning of the stomach and intestines, utilities and other services. The quantity of water consumed by each stage differs with the slaughtering. The slaughter line contains the blood and wash waters from the killing operation. Thus, the wastewater is characterised by fats, proteins and fibres leading to high organics such as chemical oxygen demand (COD) and biological oxygen demand (BOD) [4].

Usually, the wastewaters contain high amounts of biodegradable organic matter, with soluble and insoluble fractions [2], [3], [5]. Treatment of these wastewaters from slaughterhouses therefore poses some problems when compared to other agricultural processing industries. Problems encountered during treatment are the high suspended solid fats and protein contents. Another issue is the fact that some of the fats are insoluble thus lowering the rate of degradation and increasing the tendency to form scums [3]. The most common practise for slaughterhouses is the discharging of their wastewaters after a preliminary treatment to the municipality sewage where it is further treated. However, this wastewater being discharged may contain blood, solids, hair, bone pieces, hooves, fats and grease and may result in high discharge costs through municipal effluent penalty charges. Others carry out onsite treatment to reduce the pollution loads, thus trying to meet legislative requirements before discharging into receiving bodies [3], [5]. Whichever way, there are always cost implications associated with the waste management, therefore for-profit optimisation and sustainability of the environment, it is best that cost effective methods of handling these polluted waters are utilised.

Anaerobic digestion (AD) is a complex and delicate biological treatment process. It involves the degradation and stabilisation of organic matters under anaerobic conditions by 
different microbial groups of organisms. It offers various advantages over other conventional biological processes such as the recovery of valuable products like biogas (mixture of carbon dioxide and methane). Fertilizers and nutrients harvesting are other important aspects of using the AD process [1], [6], [7]. Other advantages include low sludge production and low energy requirement, thus optimising the operational costs for wastewater treatment plants (WWTPs) thereby presenting an environmental footprint which is essential for present day WWTPs [7], [8]. AD occurs naturally which can be easily affected by the operational and environmental conditions, and as such, it is expected that the natural process is optimised so that the degradation of the organics is achieved [2], [9], [10]. Due to the complexity of the $\mathrm{AD}$ process, there is a substantial chance of it becoming unstable and an eventual breakdown could occur. It is therefore paramount to have an understanding of the operations of the AD process, which enables predicting the operation of the digester. Apart from the complexity of the $\mathrm{AD}$ process, the complexity of the wastewater is another issue that comes to play with regards to the efficiency of the $\mathrm{AD}$ process. High rate anaerobic digesters are built to treat low to medium soluble strength wastewaters. However, when complex wastewaters like those that contains partially soluble wastes and a high percentage of biodegradable solids, like in the case of slaughterhouse wastewaters, only partial treatment could be achieved [10]-[13]

Sayed and DeZeeuw [12] in their study stated that the consequence of treating complex wastewater is that a significant decrease in the methanogenic capacity of the AD process could occur as a result of the coarse non-biomass suspended solids being trapped from the wastewater in the sludge. The entrapment of inert suspended solids could lead to a dilution effect of the active biomass thereby leading to a severe decrease in the methanogenic bacterial concentration in the sludge and formation of scum at the liquid interphase in the settler compartment. Thus, AD has shown to be a complex process and stands the chance of becoming unstable and eventually breakdown in the long run if not monitored properly. It is therefore important to understand the kinetics of the AD process. This can aid with the prediction of the operation of the digesting system, contributing to the understanding of the biodegradation process [14].

Therefore, the aim of this study is to elucidate the effect of process operational parameters on the performance of an upflow anaerobic sludge blanket reactor (UASB) treating slaughterhouse wastewater. OLR which is a significant parameter in the monitoring of the UASB system was varied to monitor the performance of the UASB. The formation of biomass along the height of the reactor as well as the produced biogas during the different operational conditions were studied.

\section{MATERIALS AND METHODS}

\subsection{Experimental set-up of the UASB reactor}

The reactor was constructed from Plexiglas glass with an effective working volume of 4.5 L. This comprises of three zones: the feed entrance zone, the sludge and blanket zone and the settling zone as depicted in Fig. 1. An inverse cone which served as the gas-liquid-solid separator (GLS) was installed at the top portion of the sludge bed to enhance the separation of the biogas from the liquids and solids. To reduce variations in temperature, continuous recycling of cooling water through the water jacket of the reactor was carried out using the Grant stirred thermostatic circulators water-bath (GD120). The reactor had four sampling points which were used for the monitoring of sludge production and as well as desludging of the reactor and there was no recirculation of the effluent. 


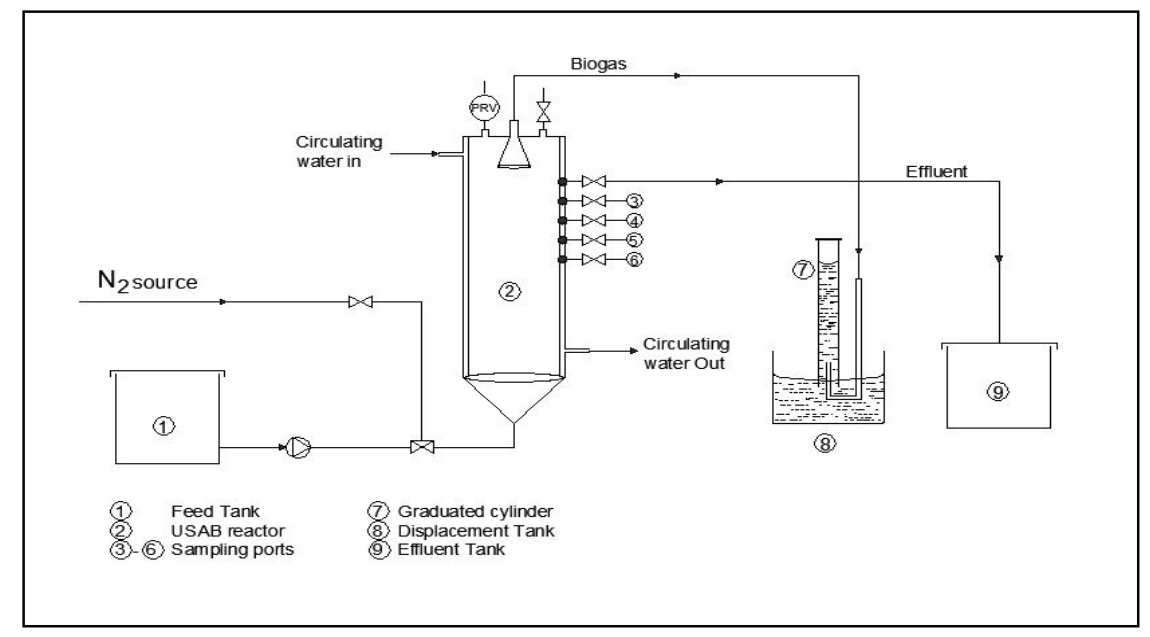

Figure 1: Schematic diagram of the experimental set-up.

\subsection{Reactor feed}

The wastewater used for this experiment was collected from a swine slaughterhouse. The samples consisted of the slaughtering operations (killing operations, wash waters from the intestines and stomach). Wastewater samples were collected twice monthly and were characterised within 24 hours of collection. Collected samples were thereafter stored at $4^{\circ} \mathrm{C}$ until the need for it. For the start-up of the reactor, it was necessary to dilute the wastewater to the required COD and this was carried out in different phases as shown in Table 1. Collected samples therefore contained lots of blood. The presence of the bloods and other substances such as fats and proteins contributed to the high organics in the wastewaters and the variations in composition as shown in Table 2.

\subsection{Operation of the UASB reactor}

The reactor was started with a digested sludge obtained from a wastewater treatment plant treating slaughterhouse wastewater from an abattoir in South Africa. The reactor was inoculated with $3 \mathrm{~L}$ of the activated sludge which was about two thirds of its working volume. Sludge was characterised to have a TSS of $19.4 \mathrm{~g} \mathrm{~L}^{-1}$ and VSS of $13.8 \mathrm{~g} \mathrm{~L}^{-1}$. The digester was

Table 1: Operational phases of the reactor.

\begin{tabular}{|c|c|c|c|}
\hline Operational phase (days) & COD $\left(\mathrm{mgL}^{-1}\right)$ & OLR $\left(\mathrm{kg} \mathrm{m}^{3} \mathrm{~d}^{-1}\right)$ & HRT \\
\hline I (1-15) & $2000-2500$ & $2.8-3$ & $\begin{array}{c}\text { First three days. 24 } \\
\text { hours and 12 hours } \\
\text { thereafter }\end{array}$ \\
\hline II (16-48) & $3000-3500$ & $3.7-4.4$ & 12 \\
\hline III (49-71) & $4000-4900$ & $5.1-6$ & 12 \\
\hline IV (72-100) & $5000-6000$ & $6.1-7.2$ & 12 \\
\hline V (101-150) & 70000 & $8-10$ & 12 \\
\hline
\end{tabular}


Table 2: Characteristics of wastewaters resulting from various slaughterhouses (number of samples $=24)$.

\begin{tabular}{|l|c|c|c|}
\hline Parameter & Influent & Average & Standard deviation \\
\hline Chemical oxygen demand (COD) & $3000-6030$ & 4326.3 & \pm 1163.4 \\
\hline Total suspended solids (TSS) & $1500-4600$ & 2352.4 & \pm 210.4 \\
\hline Total organic carbon (TOC) & $200-950$ & 667.68 & \pm 262.92 \\
\hline Volatile suspended solids (VSS) & $1100-1500$ & 1208.9 & \pm 103.6 \\
\hline Volatile fatty acid (VFA) & $440-820$ & 727.45 & \pm 143.56 \\
\hline Alkalinity & $1100-2600$ & 2193 & \pm 542.16 \\
\hline TKN & $110-250$ & 83.4 & \pm 35.8 \\
\hline Total nitrogen (TN) & $50-95$ & 79.52 & \pm 9.42 \\
\hline Total ammonia (TAN) & $110-185$ & 153.72 & \pm 20.73 \\
\hline Nitrates and Nitrites $\left(\mathrm{NO}_{3-}-\mathrm{N}+\mathrm{NO}_{2-} \mathrm{N}\right)$ & $2.82-5.7$ & 4.9 & \pm 0.3 \\
\hline pH & $6.3-7.3$ & 6.9 & \pm 0.13 \\
\hline
\end{tabular}

*All units in $\mathrm{mgL}^{-1}$ except $\mathrm{pH}$

fed on a continuous basis at a flowrate of $0.25 \mathrm{~L} / \mathrm{hr}$ from the bottom of the reactor by the use of a Cole palmer masterflex peristaltic pump (Model 77521-50) at the rate defined by the HRT of $12 \mathrm{~h}$. However, for the first three days of the start-up, the reactor was operated in a batch mode at a HRT of 24 hours and thereafter, the continuous mode was used. An OLR of $1.54 \mathrm{~kg} \mathrm{~m}^{-3} \mathrm{~d}^{-1}$ was used for the first 3 days to enable stabilisation of the reactor, and thereafter, the OLR was increased stepwise as the treatment efficiency of the reactor improved with time.

The biogas produced was channelled through the gas outline as shown in Fig. 1 and was passed through $3 \mathrm{M} \mathrm{NaOH}$ solution so as to capture the $\mathrm{CO}_{2}$ present in the biogas [15]. The biogas present was measured volumetrically by the displacement of water as shown in Fig. 1. The produced gas was measured on a daily basis to enable the ease in which the system kinetics was followed. To obtain a stable operation of the reactor, the temperature of the reactor was maintained at $35^{\circ} \mathrm{C}$ with the use of a water bath. Reactor efficiency was evaluated by monitoring the removal of organics using the eqn 1 .

$$
\text { Reactor effciency }=\left(1-\frac{C O D_{\text {out }}}{C O D_{\text {in }}}\right) \times 100
$$

\subsection{Analytical methods}

The following physico-chemical properties were determined: chemical oxygen demand (COD), biological oxygen demand (BOD), total suspended solids (TSS), volatile suspended solids (VSS), total solids (TS), $\mathrm{pH}$, nitrites $\left(\mathrm{NO}_{2}\right)$, nitrates $\left(\mathrm{NO}_{3}\right)$ and total ammonia nitrogen $\left(\mathrm{NH}_{3}-\mathrm{N}\right)$, VFA and alkalinity. The parameters were evaluated following the procedure for standard methods for the examination of water and wastewater [15]. Both TSS and VSS were determined by the drying of homogenised samples at $103^{\circ} \mathrm{C}$ for $24 \mathrm{~h}$ for TSS and furthermore, VSS was obtained by incinerating the dried fractions in a muffle furnace at $550^{\circ} \mathrm{C}$ for $1 \mathrm{~h}$. COD was determined using close refluxing according to the standard method 5220D. The $\mathrm{pH}$ and temperature were measured using a $\mathrm{pH}$ meter (Orion) and thermometer respectively.

The total nitrogen $(\mathrm{TN})$, TKN and nitrates nitrogen $\left(\mathrm{NO}_{3}-\mathrm{N}\right)$ and nitrites nitrogen $\left(\mathrm{NO}_{2}-\mathrm{N}\right)$ concentration was determined using HACH kit (Simplified TKN TNT plus, TNT880, method 10242) and Total ammonia nitrogen (TAN) concentration was determined using HACH kit (Simplified TKN TNT plus, TNT832, method 10205) [16], [17]. VFA was 
by the distillation of sample and titrating the distillate with the use of $0.1 \mathrm{~N}$ sodium hydroxide to $\mathrm{pH}$ 8.3. Total alkalinity was determined by titration of the samples with sulfuric acid $(0.1 \mathrm{~N})$ to $\mathrm{pH} 4.0$ [18]. The $\mathrm{pH}$, temperature and COD were analysed every day during the start-up of the reactor, continuously even after the start-up. Once the reactors had stabilised, TSS and VSS were analysed weekly for the duration of the experiment. Other parameters such as VFA and alkalinity, TKN and TAN were determined biweekly.

\section{RESULTS AND DISCUSSION}

\subsection{Reactor start-up}

The reactor start-up is reported as the period taken for stable operation of the reactor to occur. During this stage, the microorganisms are being acclimatised to the new environmental conditions and substrate. An equilibrium is also slowly being established between the various microorganisms present in the system, until the biomass is stable and efficient to degrade the substrate at the targeted OLR [13]. Reactor start-up has been reported as a complicated process, and as such the monitoring of both environmental and operating conditions is important [19].

The VSS/TSS is significant because it is an indication of the amount of biomass in the total sludge measured as suspended solids. A high ratio of VSS/TSS in the inoculum to be used for the reactor start-up is important [20]. For the start-up, the VSS/TSS ratio was about 0.71 . This ratio continued to increase (as observed in Fig. 7), which is an indication of microorganism's adaptation and multiplication. Feed concentration of less than $3000 \mathrm{mg} \mathrm{L}^{-1}$ of COD $\left(2.8 \mathrm{~kg} \mathrm{~m}^{-3} \mathrm{~d}^{-1}\right)$ was used for the start-up to help in preventing and controlling the excessive generation of VFA since at this stage the microorganisms were still adapting to the new environment.

The wastewater samples collected were analysed and characterised and presented in Table 2. Results reported are averages taken in duplicates as well as the standard deviations. The performance of the reactor was assessed based on the biogas production and the reduction of organics. Other factors such as VFA, alkalinity, TSS and VSS were factors monitored to evaluate treatment efficiency of the reactor. The characterisation of the effluent in Table 2 shows that the wastewaters from the slaughterhouse can be regarded as high strength wastewaters according to the classification by Cao and Mehrvar [5]. Observable from Table 2 is the variation in the influent of the wastewater used for the experiment. The changes in the influent concentration have a great impact on the performance of the reactor (Fig. 1). The reason for such was attributed to the different processes involved during slaughtering as well as other housekeeping issues.

\subsection{Performance of the UASB reactor}

Following the successful start-up of the reactor with the low initial OLR $\left(2.8 \mathrm{~kg} \mathrm{~m}^{-3} \mathrm{~d}^{-1}\right)$, the reactor was gradually loaded with a higher OLR with the slaughterhouse wastewater as the substrate by increasing the COD concentration and keeping HRT constant. Each loading rate was allowed a time of stability as shown in Table 1 . To evaluate the optimum loading rate, OLR was increased to $10 \mathrm{~kg} \mathrm{COD} \mathrm{m}^{-3} \mathrm{~d}^{-1}$. The performance of the reactor is presented in the following sections. 


\subsection{Effect of OLR on $\mathrm{pH}$}

Fig. 2 shows the daily $\mathrm{pH}$ and OLR in the reactor. In the AD system, the different microorganisms have different optimum $\mathrm{pH}$ values for maximum performance. The methanogenic bacteria, which are responsible for the production of methane, are more sensitive to $\mathrm{pH}$, optimally between $\mathrm{pH} 6.5$ and 7.5 [21]. The OLR rate describes the liquid flowrate and contaminants concentration and it is said to be the mass of the pollutants that is introduced into the given reactor at a time. Therefore, it combines the reactor characteristics, the operating characteristics and finally mass of the bacteria activity into the volume of media [22].

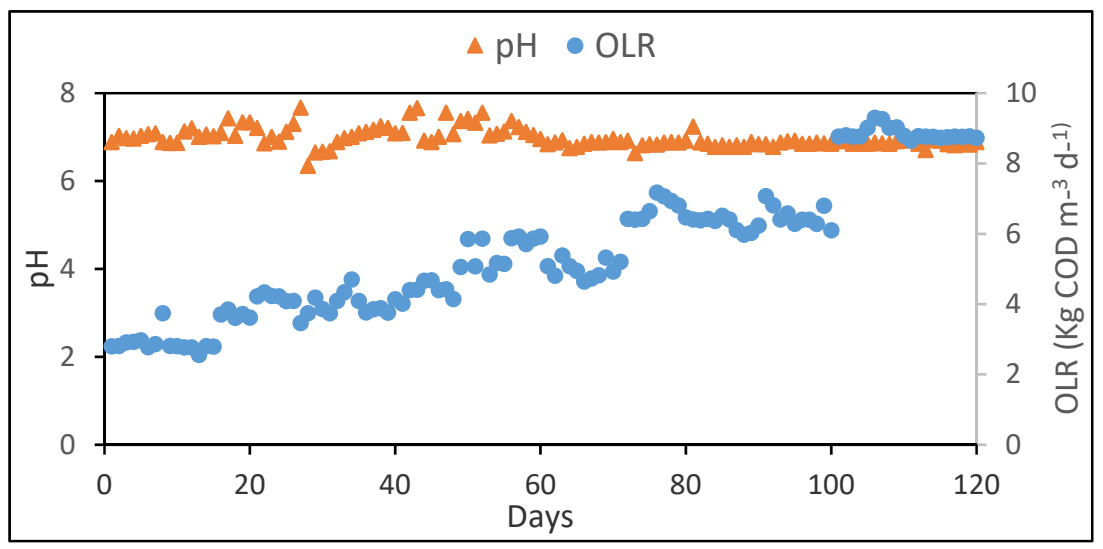

Figure 2: Daily $\mathrm{pH}$ and OLR of the UASB reactor.

The influent $\mathrm{pH}$ for the wastewater samples were relatively stable between 6.8 and 7.1 , so the data is not presented. For the effluent $\mathrm{pH}$, it was between 6.64 on the low and 7.67 for the high as illustrated in Fig. 2. The lowest $\mathrm{pH}$ was recorded on the 18th day as 6.64 while the maximum $\mathrm{pH}$ was 7.67 which was on the 27th day. Buffering of the system was not carried out because the reactor's $\mathrm{pH}$ was at most times within the required range for the organisms. The $\mathrm{pH}$ levels during the experimental period were favourable to the methanogens bacteria. Several authors have reported that methanogenesis in anaerobic digestion occurred efficiently at $\mathrm{pH} 6.5-8.2$ while hydrolysis and acidogenesis occurred at $\mathrm{pH} 5.5$ and 6.5. The ability of the system to perform to its capacity is much dependant on the $\mathrm{pH}$ such that reactor failure or underperformance could occur. Several studies have reported such occurrences [23], [24].

Fig. 3 shows the average weekly $\mathrm{pH}$ with respect to alkalinity. It was observed that the alkalinity of the reactor was above $1,000 \mathrm{mg} \mathrm{L}^{-1} \mathrm{CaCO}_{3}$ for the bulk of the time, however, for the first week of the reactor start-up, the alkalinity was below $1,000 \mathrm{mg} \mathrm{L}^{-1} \mathrm{CaCO}_{3}$. At this stage, the microorganisms were still adapting to the new conditions which they were exposed to. It was also observed that from the 14th week, the $\mathrm{pH}$ of the reactor had begun to decline even though the alkalinity was relatively stable. The drop in the $\mathrm{pH}$ values were, however, not detrimental to the reactor because it was still within the optimal limits suggested for the anaerobic processes. 
Successively, wastewaters from the slaughterhouse have been indicated to be rich in proteins. The mineralisation of these proteins to ammonia is responsible for the increased alkalinity as the OLR increased as shown in Figs 3 and 4. Fig. 4 further elaborates the relationship between VFA and alkalinity of the reactor. The ratios of the VFA to alkalinity were found to be below 0.4 except during the start-up period where it was slightly above, however, it stabilised soon afterwards as the system became stabilised, indicating it was favourable [9], [15].

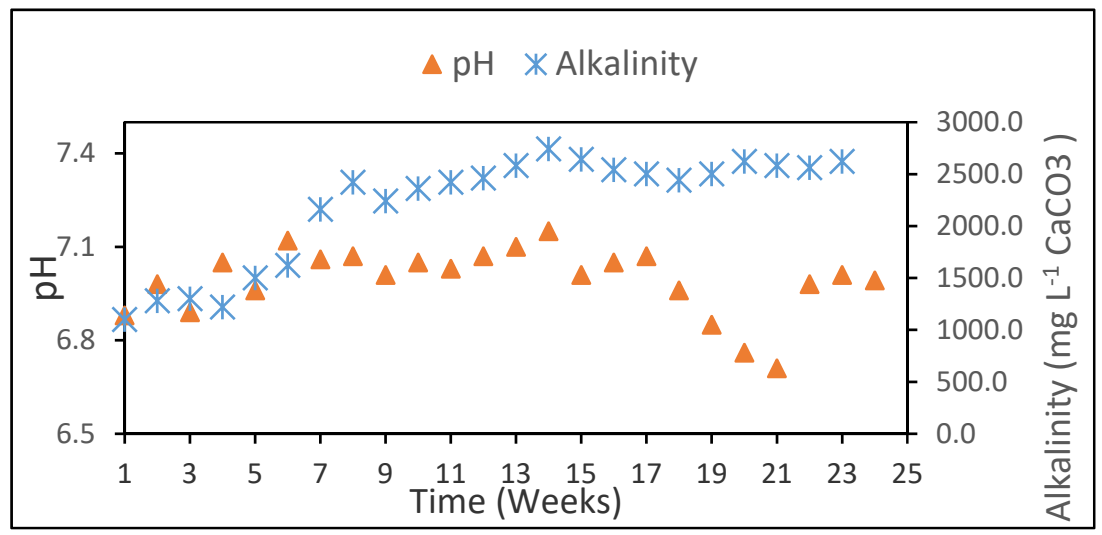

Figure 3: Weekly $\mathrm{pH}$ and alkalinity of the reactor.

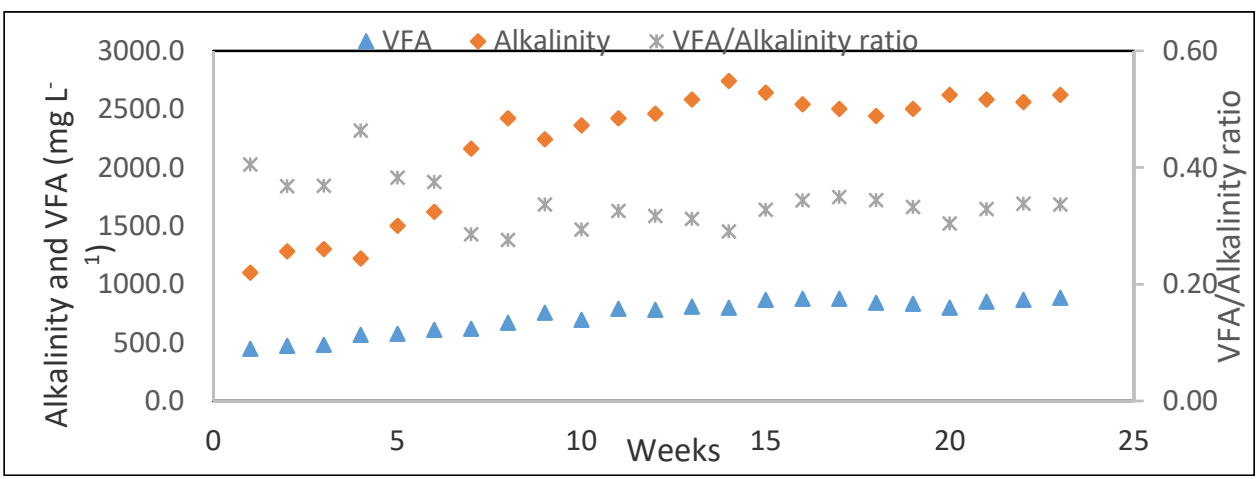

Figure 4: Weekly alkalinity, VFA and VFA/alkalinity ratio of the reactor.

VFAs in the system ranged from 445 on the first week to $882 \mathrm{mg} \mathrm{L}^{-1}$ on the $23 \mathrm{rd}$ week. The increase in the VFAs was attributed to the increase in OLR. Even though this increase was observed, the produced alkalinity was able to buffer the VFAs produced. The $\mathrm{pH}$ and alkalinity indicated that the system was able to produce enough $\mathrm{CaCO}_{3}$ to be able to neutralise the volatile fatty acids (VFAs) in the system, thus acting as a buffer. Again, the continued increase in the production of biogas (Fig. 6) was an indicator that each of these factors had not impacted on the reactor to a point of inhibition, thus, indicating the activeness of the methanogenic bacteria. At this point it is worth mentioning that the methanisation of COD was rapid as compared to the particulate hydrolysis [13]. 


\subsection{Effect of OLR on COD reduction}

Fig. 5 shows the influent and effluent of the total COD as well as the COD removal efficiency. The OLR was introduced in a stepwise manner from $2.28 \mathrm{~kg} \mathrm{COD} \mathrm{m}^{-3} \mathrm{~d}^{-1}$ to $9 \mathrm{~kg} \mathrm{COD} \mathrm{m}^{-3}$ $\mathrm{d}^{-1}$. During the start-up of the reactor, the removal efficiency was low, below $30 \%$, even at a low OLR rate of $2.28 \mathrm{~kg} \mathrm{COD} \mathrm{m} \mathrm{d}^{-1}$. However, as shown in Fig. 5, COD removal efficiencies showed an increasing trend from a low $37 \%$ to a maximum of $86 \%$, (day 42 and OLR 4.2-5 $\left.\mathrm{kg} \mathrm{COD} \mathrm{m}^{-3} \mathrm{~d}^{-1}\right)$. At the start of each phase of OLR, there was a corresponding decrease in removal efficiencies. Observable also was the fact that as OLR increased from 5 to $9 \mathrm{~kg} \mathrm{COD} \mathrm{m} \mathrm{m}^{-3} \mathrm{~d}^{-1}$, an obvious reduction in the COD removal to $60-70 \%$ occurred. The reduction in the COD removal efficiency indicated that the microorganisms could not flourish at a higher level of OLR. Chollom et al. [4] and Torkian et al. [25] in their studies observed that, as OLR increased, the adaptation of the microbial community to the new condition is retarded thus leading to a decrease in the performance of the system. But the recovery of this is usually within a period of 24 hours in most cases as can be seen in Fig. 5 for each new influent. OLR is said to play a significant role in the reactor efficiency.

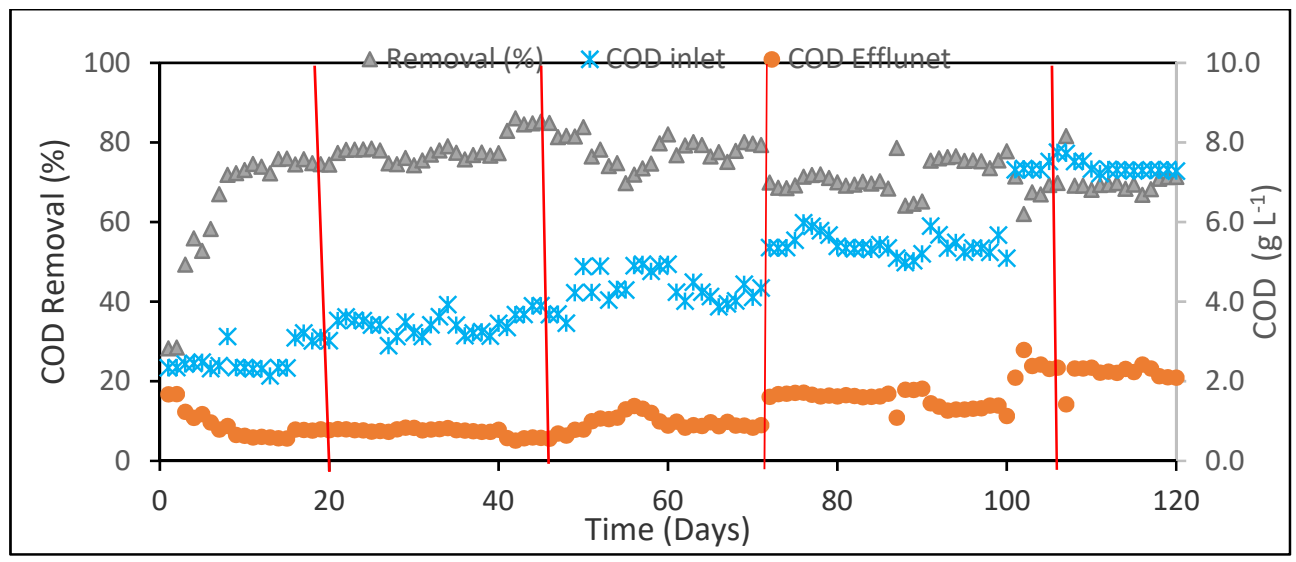

Figure 5: Influent and effluent COD and percentage of COD removal of the UASB reactor.

The average removal for the experimental period was $73 \%$ and the maximum COD removal of $80-84 \%$ was achieved at OLR of $4-5 \mathrm{~kg} \mathrm{COD} \mathrm{m}^{-3} \mathrm{~d}^{-1}$. While removal in this study was said to be above the optimum required for anaerobic treatment units, the values obtained were below those treating similar wastewaters. Borja et al. [26] reported COD removal efficiencies of $64-99 \%$ at OLR values of $12-17 \mathrm{~kg} \mathrm{COD} \mathrm{m}^{-3} \mathrm{~d}^{-1}$. Again, Ruiz et al. [22] reported a $92 \%$ soluble COD (SCOD) removal at $5.2 \mathrm{~kg} \mathrm{SCOD} \mathrm{m}^{-3} \mathrm{~d}^{-1}$ and HRT of 1.2 days. From day 100, when the OLR was changed from 6 to $9 \mathrm{~kg} \mathrm{COD} \mathrm{m}^{-3} \mathrm{~d}^{-1}$, a slight sludge washout was observed and hence a lower efficiency of $70-75 \%$ was achieved. Higher removal rates of $76.2 \%$ have been reported by Borja et al. [27] at OLR of $17.8 \mathrm{~kg} \mathrm{COD} \mathrm{m}^{-3}$ $\mathrm{d}^{-1}$ when treating wastewaters from virgin olive oil.

\subsection{Effect of OLR on biogas production}

Fig. 6 illustrates the relationship between OLR of the reactor and the biogas produced. Biogas production during the start-up period is usually the lowest due to the fact that the growth rate 
of the methane generating microorganisms is slow as compared to the acid forming microorganisms. As seen in Fig. 6, however, an increasing trend of biogas over time was observed in the system indicating that as the days progressed, the microorganisms were stabilised and were thriving to the new OLR, hence, contributing to the increase of biogas production.

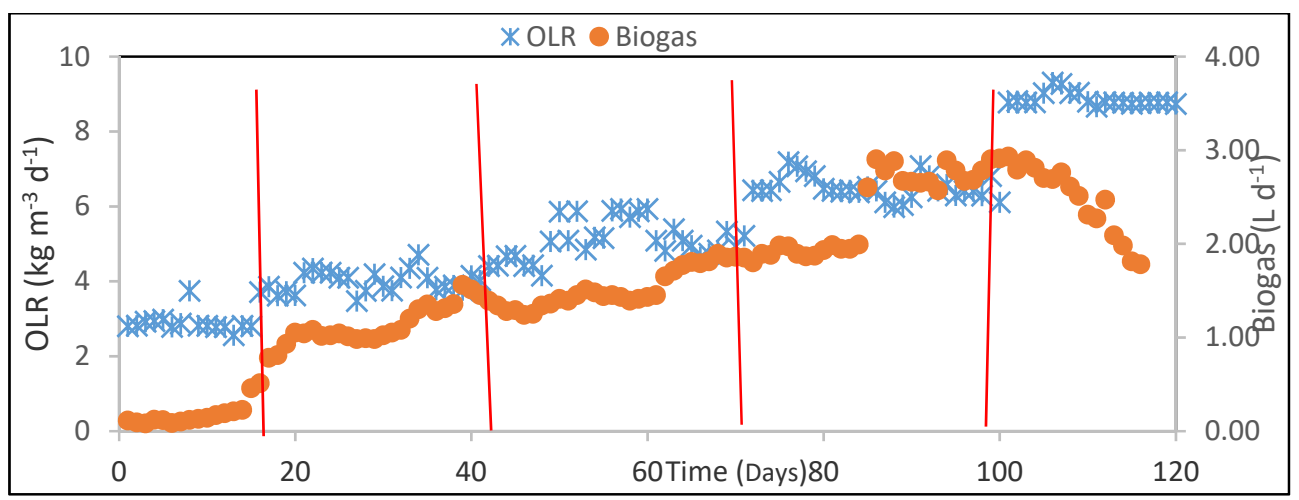

Figure 6: Applied OLR and the biogas production rate.

The results therefore indicated a strong relation between OLR and biogas production. Biogas production was observed to increase with the introduction of a new OLR indicating the availability of more substrate for digestion. However, just after the introduction of a new OLR, a decrease in biogas was observed, but picked up soon afterwards. The reason for that was the adaptation of the microorganisms to the new conditions introduced, as earlier indicated for the COD removal. Once the microorganisms were adapted, a gradual increase was observed which tends toward stability until the next phase of introduction.

Observable from Fig. 6 is the fluctuation in the biogas production. Such variation was reported to be as a result of the changes in the biological degradation of the effluent and the possible presence of different organic and inorganic materials that inhibited the treatment performance [22].

On days 100 and 101 the highest OLR of $9 \mathrm{~kg} \mathrm{COD} \mathrm{m}^{-3} \mathrm{~d}^{-1}$ was introduced and $8.63 \mathrm{~L}$ day $^{-1}$ of biogas was produced. This was the maximum obtained, however, this gradually began to reduce, as seen in the following days. The reason was attributed to the increase in the VFA contents in the reactor and reduction in total alkalinity, as earlier indicated in Fig. 4 on the alkalinity and VFA of the reactor, the effect of which would have impacted on the production of the biogas. Ruiz et al. [22] attributed this behaviour to the attachment of gas bubbles at higher OLR, which was said to have contributed to the suspension of biomass and cell washout. This effect was more pronounced as the biogas production increased.

\subsubsection{Biomass accumulation and sludge bed characteristics}

The behaviour of the sludge bed in the reactor was analysed using the sampling points as shown in Fig. 1. There were four sampling points on the reactor, and each point showed distinct characteristics. Results of the weekly TSS and VSS are shown in Fig. 7. The sludge characteristics inside the reactor was found to settle easily. The rate of sludge production at the start-up of the reactor was slow but it picked up with time. This indicated that most of the soluble as well as settled matter in the wastewater were degraded during the treatment in 
the reactor. Similar findings were reported by Ruiz et al. [22]. Sludge washout became noticeable as the biogas production rate increased with the OLR. Even though this was experienced, it did not cause sludge bulking in the system. Some studies had indicated a few factors responsible for the sludge washout in their studies; increase in gas production due to high OLR and high relative content of coarse suspended solids in influent [27]. Ruiz et al. [22] reported on the floatation of sludge and an increase in the effluent solids at OLR values greater than $5 \mathrm{~kg} \mathrm{COD} \mathrm{m}^{-3} \mathrm{~d}^{-1}$.

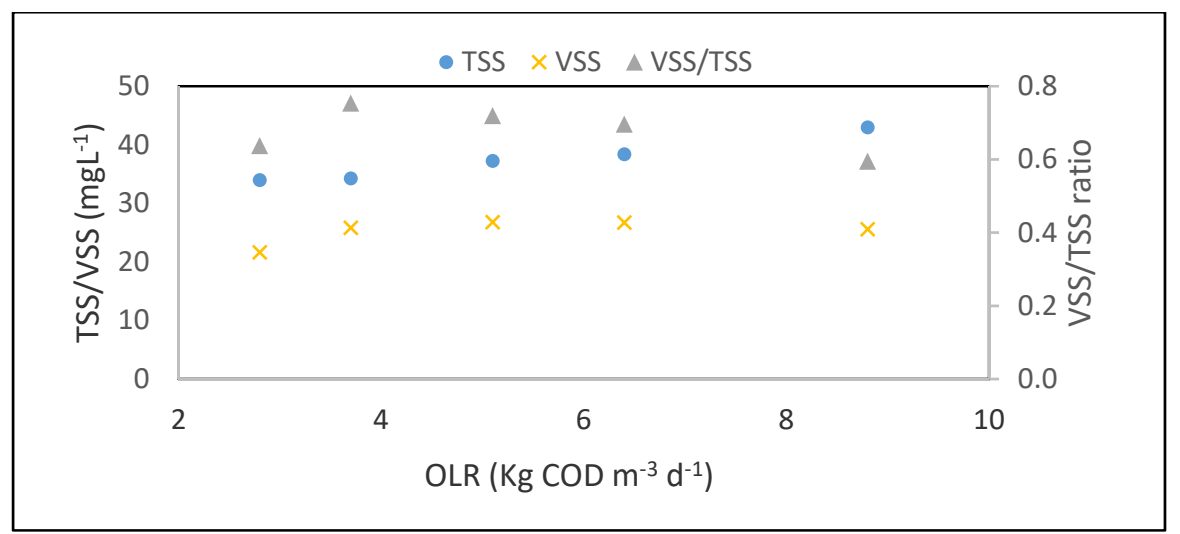

Figure 7: Weekly variation of TSS and VSS with OLR.

\section{CONCLUSION}

The result from this study demonstrated that the anaerobic treatment of slaughterhouse wastewaters from the slaughtering section is effective for the removal of COD and generation of biogas. Averagely, COD removal efficiency higher than 75\% was achieved at OLR of 9 $\mathrm{kg}$ COD m-3 d-1, with a HRT of $12 \mathrm{~h}$. Bulking sludge problems were not observed during the reactor operation period. Stability of the treatment process was achieved by the natural buffering of the system due to the produced alkalinity and also due to the characteristics of the wastewaters which is found to be rich in proteins. While this system exhibited the tendencies to produce bioenergy, it is necessary to carry out an economic analysis on the utilization of biogas, especially the methane produced as a source of energy.

\section{ACKNOWLEDGEMENTS}

The authors wish to thank the Durban University of Technology and the National Research Foundation (NRF) of South Africa for their support.

\section{REFERENCES}

[1] Bustillo-Lecompte, C.F. \& Mehrvar, M., Treatment of an actual slaughterhouse wastewater by integration of biological and advanced oxidation processes: Modeling, optimization, and cost-effectiveness analysis. Journal of Environmental Management, 182, pp. 651-666, 2016.

[2] Bustillo-Lecompte, C.F. \& Mehrvar, M., Slaughterhouse wastewater characteristics, treatment, and management in the meat processing industry: A review on trends and advances. Journal of Environmental Management, 161, pp. 287-302, 2015. 
[3] Escudero, A., Lacalle, A., Blanco, F., Pinto, M., Díaz, I. \& Domínguez, A., Semicontinuous anaerobic digestion of solid slaughterhouse waste. Journal of Environmental Chemical Engineering, 2(2), pp. 819-825, 2014.

[4] Chollom, M., Rathilal, S., Swalaha, F., Bakare, B. \& Tetteh, E., Study of the start-up of an upflow laboratory-scale anaerobic sludge blanket for the treatment of slaughterhouse wastewater. 4th Water and Society IV, WIT Transactions on Ecology and the Environment, Seville, 2016.

[5] Cao, W. \& Mehrvar, M., Slaughterhouse wastewater treatment by combined anaerobic baffled reactor and $\mathrm{UV} / \mathrm{H}_{2} \mathrm{O}_{2}$ processes. Chemical Engineering Research and Design, 89(7), pp. 1136-1143, 2011.

[6] Wang, P., Wang, H., Qiu, Y., Ren, L. \& Jiang, B., Microbial characteristics in anaerobic digestion process of food waste for methane production: A review. Bioresource Technology, 248, pp. 29-36, 2018.

[7] Appels, L., Baeyens, J., Degréve, J. \& Dewil, R., Principles and potential of the anaerobic digestion of waste-activated sludge. Progress in Energy and Combustion Science, 34(6), pp. 755-781, 2008.

[8] Sindhu, R. \& Meera, V., Treatment of slaughterhouse effluent using upflow anaerobic packed bed reactor. International Congress on Informatics, Environment, Energy and Applications, Singapore, 2012.

[9] Jijai, S., Srisuwan, G., O-thong, S., Ismail, N. \& Siripatana, C., Effect of granule sizes on the performance of upflow anaerobic sludge blanket (UASB) reactors for cassava wastewater treatment. Energy Procedia, 79, pp. 90-97, 2015.

[10] Moukazis, I., Pellera, F.M. \& Gidarakos, E., Slaughterhouse by-products treatment using anaerobic digestion. Waste Management, 71, pp. 652-662, 2018.

[11] Chong, S., Sen, T.K., Kayaalp, A. \& Ang, H.M., The performance enhancements of upflow anaerobic sludge blanket (UASB) reactors for domestic sludge treatment: A State-of-the-art review. Water Research, 46(11), pp. 3434-3470, 2012.

[12] Sayed, S.K. \& DeZeeuw, W., The performance of a continuously operated flocculent sludge UASB reactor with slaughterhouse wastewater. Biological Wastes, 24(3), pp. 199-212, 1988.

[13] Masse, O. \& Masse, L., Treatment of slaughterhouse wastewater in anaerobic sequencing batch reactors. Can. Agr. Eng., 42, pp. 131-137, 2000.

[14] Padilla-Gasca, E., Lopez-Lpoez, A. \& Gallardo-Valdez, J., Evaluation of stability factors in the anaerobic treatment of slaughterhouse wastewater. Journal of Bioremediation and Biodegradation, 2(1), pp. 1-5, 2011.

[15] APHA-AWWA-WPCF, Standard Methods for the Examination of Water and Wastewater, 20th ed., American Public Health Association/American Water Works Association/Water Environment Federation: Washington, DC, 1998.

[16] Pandey, P.K., Cao, W., Biswas, S. \& Vaddella, V., A new closed loop heating system for composting of green and food wastes. Journal of Cleaner Production, 133, pp. 1252-1259, 2016.

[17] Cai, T., Park, S.Y., Racharaks, R. \& Li, Y., Cultivation of nannochloropsis salina using anaerobic digestion effluent as a nutrient source for biofuel production. Applied Energy, 108, pp. 486-492, 2013.

[18] Rajesh Banu, J., Anandan, S., Kaliappan, S., Yeom, L.-T., Treatment of dairy wastewater using anaerobic and solar photocatalytic methods. Solar Energy, 82, pp. 812-819, 2008. 
[19] Rizvi, H. et al., Start-up of UASB reactors treating municipal wastewater and effect of temperature/sludge age and hydraulic retention time (HRT) on its performance. Arabian Journal of Chemistry, 8(6), pp. 780-786, 2015.

[20] Vlyssides, A., Barampouti, E. \& Mai, S., Influence of ferrous iron on the granularity of a UASB reactor. Chemical Engineering Journal, 146(1), pp. 49-56, 2009.

[21] Ward, A.J., Hobbs, P.J., Holliman, P.J. \& Jones, D.L., Optimisation of the anaerobic digestion of agricultural resources. Bioresource Technology, 99(17), pp. 7928-7940, 2008.

[22] Ruiz, I., Veiga, M., Santiago, P.D. \& Blázquez, R., Treatment of slaughterhouse wastewater in a UASB reactor and an anaerobic filter. Bioresource Technology, 60, pp. 251-258, 1997.

[23] Khalid, A., Arshad, M., Anjum, M., Mahmood, T. \& Dawson, L., The anaerobic digestion of solid organic waste. Waste Management, 31(8), pp. 1737-1744, 2011.

[24] Ren, Y. et al., A comprehensive review on food waste anaerobic digestion: Research updates and tendencies. Bioresource Technology, 247, pp. 1069-1076, 2018.

[25] Torkian, A., Eqbali, A. \& Hashemian, S.J., The effect of organic loading rate on the performance of UASB reactor treating slaughterhouse effluent. Resources, Conservation and Recycling, 40(1), pp. 1-11, 2003.

[26] Borja, R., Banks, C.J. \& Wang, Z., Performance and kinetics of an upflow anaerobic sludge blanket (UASB) reactor treating slaughterhouse wastewater. Journal of Environmental Science and Health, 29, pp. 2063-2085, 1994.

[27] Borja, R., Alba, J. \& Banks, C.J., Anaerobic digestion of wash waters derived from the purification of virgin olive oil using a hybrid reactor combining a filter and a sludge blanket. Process Biochemistry, 31(3), pp. 219-224, 1996. 